\title{
Hubungan Motivasi Berprestasi Minat dan Perhatian Orang Tua Terhadap Hasil Belajar Kognitif Biologi Siswa SMA Negeri Se-Kecamatan Medan Kota
}

\author{
Intan Bayati Nasution, Hasruddin, Syahmi Edi \\ Program Studi Pendidikan Biologi, Program Pascasarjana, Universitas Negeri Medan \\ J1. Willem Iskandar Pasar V Medan Estate, Deli Serdang, Sumatera Utara, Indonesia \\ *Email : intan_qyoot@yahoo.com
}

\begin{abstract}
This study aims to determine the relationships between: (1) Achievement motivation; (2) Interest; (3) Carefullness of parents toward biology cognitive learning outcome; (4) Achievement motivation and interest; (5) Achievement motivation and carefullness of parents; (6) Interest and carefullness of parents together on biology cognitive learning outcome. This study was conducted at SMA Sekecamatan Medan Kota. The study method using is correlational descriptive with study sample as much as 275 students' who are by purposive sampling that's are SMA Negeri 5 as much as 138 students', SMA Negeri 6 as much as 65 students', and SMA Negeri 10 as much as 72 students'. The study instrument using questionnaire of achievement motivation with total 30 statement, questionnaire of interest with total 20 statement, questionnaire of carefullness of parents with total 25 statement, whereas value of biology cognitive learning outcome resulted from biology result semester I which there are in each school. Analysis techniques used is correlation with the help program SPSS 21.0 for windows. The stuy result shows that there are significant relationship between: (1) Achievement motivation toward biology cognitive learning outcome $(r=0,536 ; p=0,000)$; (2) Interest toward biology cognitive learning outcome $(\mathrm{r}=0,482 ; \mathrm{p}=0,000)$; (3) Carefullness of parents toward biology cognitive learning outcome $(\mathrm{r}=0,250 ; \mathrm{p}=0,000)$; (4) Achievement motivation and interest together on biology cognitive learning outcome $(\mathrm{r}=0,603 ; \mathrm{p}=0,000) ;(5)$ Achievement motivation and carefullness of parents together on biology cognitive learning outcome $(\mathrm{r}=0,546 ; \mathrm{p}=0,000) ;(6)$ Interest and carefullness of parents together on biology cognitive learning outcome $(\mathrm{r}=0,499$; $\mathrm{p}=0,000)$.
\end{abstract}

Key Words: Achievement motivation, Interest, Carefullness of Parents, Biology Cognitive Learning Outcome.

\section{PENDAHULUAN}

Banyak permasalahan yang timbul dalam proses pembelajaran biologi di sekolah-sekolah. Permasalahan yang sering dijumpai dalam proses pembelajaran biologi adalah rendahnya pemahaman dan minat belajar siswa. Minat mempunyai peranan yang sangat penting dalam belajar.

Keberhasilan belajar sering disebabkan adanya motivasi yang kuat. Motivasi berprestasi merupakan suatu usaha yang disadari dari dalam diri siswa yang mampu mendorong siswa untuk belajar, mengerjakan tugas-tugas, memecahkan masalah serta menggerakkan dan mengarahkan dirinya untuk mencapai prestasi yang diinginkan (Yamin, 2008: 97).

Motivasi berprestasi sangat penting dalam belajar karena seseorang yang memiliki motivasi berprestasi yang kuat cenderung akan melakukan berbagai upaya untuk dapat menguasai bidang yang dipelajarinya sehingga dapat mencapai prestasi yang lebih tinggi. Motivasi berprestasi merupakan faktor internal dalam pembelajaran yang memberi kontribusi besar yaitu $64 \%$ dalam menentukan prestasi belajar seseorang (Mc Chelland dalam Siregar dan Nara, 2010:52). Hal ini menunjukkan bahwa motivasi berprestasi memiliki hubungan erat terhadap pencapaian hasil belajar.

Keluarga berperan besar dalam perkembangan individu, dimana para orang tua yang mendorong, membantu dan mengharapkan anak-anaknya dapat mandiri pada usia muda maka anaknya akan mempunyai internal locus of control yaitu memiliki tanggung jawab atas segala perbuatannya (Soemanto, 1990). 
Bentuk-bentuk perhatian orang tua terhadap hasil belajar anak adalah : bimbingan, motivasi dan penghargaan, pengawasan, pemenuhan fasilitas belajar, dan pemeliharaan kesehatan jasmani dan rohani.

\section{METODE PENELITIAN}

\section{Tempat dan Waktu Penelitian}

Penelitian ini telah dilaksanakan di SMA Negeri se-Kecamatan Medan Kota yaitu SMA Negeri 5, SMA Negeri 6 dan SMA Negeri 10 Medan. Waktu penelitian ini telah dilaksanakan pada bulan FebruariApril 2016.

\section{Populasi dan Sampel}

Populasi yang dijadikan sebagai objek penelitian adalah seluruh siswa kelas XI Sekolah Menengah Atas (SMA) Negeri yang ada di se- Kecamatan Medan Kota. Sampel penelitian ini diambil dengan teknik Purposive Sampling, jumlah sampel sebanyak 275 siswa.

\section{Desain Penelitian}

Penelitian ini dilaksanakan mengikuti metode penelitian ex-postfacto yaitu penelitian dimana rangkaian variabelvariabel bebas telah terjadi ketika peneliti mulai melakukan pengamatan terhadap variabel terikat.

Pada penelitian ini penelitian expostfacto masuk dalam kelompok deskriptif korelasional yang bertujuan untuk membuat pencandraan secara sistematis, faktual dan akurat mengenai fakta dan sifat-sifat populasi atau daerah tertentu yang mengaitkan antara motivasi berprestasi,minat dan perhatian orang tua terhadap hasil belajar kognitif biologi. Rancangan penelitian adalah angket motivasi berprestasi, angket minat, angket perhatian orang tua, dokumentasi hasil belajar kognitif biologi.

\section{Teknik Analisis Data}

Adapun teknik analisis data yang dilakukan pada penelitian ini adalah statistik deskriptif dan inferensial. Seluruh data dianalisis dengan menggunakan SPSS 21.0 for windows.

\section{Uji Prasyarat}

\section{Uji Normalitas Data}

Uji normalitas data dimaksudkan untuk menentukan normal tidaknya distribusi data penelitian, artinya apakah penyebarannya dalam populasi bersifat normal. Normalitas data diuji dengan menggunakan pendekatan KolmogorovSmirnov. Data dinyatakan berdistribusi normal apabila Sig $<0,05$.

\section{Uji Homogenitas Data}

Uji homogenitas data dimaksudkan untuk mengetahui perbedaan varians data. Homogenitas data diuji dengan pendekatan Levene's Test. Data dinyatakan memiliki varians yang sama (homogen) jika nilai Sig $<0,05$.

\section{Uji Lineritas Data}

Uji linieritas data dimaksudkan untuk mengetahui apakah data berdistribusi pola linier. Linieritas data diuji dengan uji $F$, dengan kriteria uji, apabila nilai $r$ lebih kecil atau sama dengan dari tingkat $\alpha$ (Sig $<0,05)$ maka data berdistribusi pola linier.

\section{Uji Analisis Korelasi Parsial dan Ganda}

Untuk menguji hipotesis penelitian antara variabel $X_{1}$ dengan $Y_{1}, X_{2}$ dengan $Y_{1}, X_{3}$ dengan $Y_{1}, X_{1}$ dan $X_{2}$ dengan $Y_{1}$, $X_{1}$ dan $X_{3}$ dengan $Y_{1}, X_{2}$ dan $X_{3}$ dengan $\mathrm{Y}_{1}$ digunakan teknik korelasi dengan menggunakan rumus Pearson Product Moment. Korelasi PPM dilambangkan (r) dengan ketentuan nilai $\mathrm{r}$ tidak lebih dari harga $(-1 \leq \mathrm{r} \leq+1)$. Apabila nilai $\mathrm{r}=-1$ artinya korelasinya negatif sempurna, $r=0$ artinya tidak ada korelasi dan $r=1$ berarti korelasinya sangat kuat. Sedangkan arti harga $r$ akan dikonsultasikan dengan Tabel interpretasi Nilai r.

Pengujian lanjutan yaitu uji signifikansi yang berfungsi untuk mencari makna hubungan variabel $\mathrm{X}$ terhadap $\mathrm{Y}$, maka hasil korelasi PPM diuji dengan Ujit. Data bersifat signifikan apabila Sig < 0,05 .

Selanjutnya untuk menyatakan besar kecilnya sumbangan variabel $\mathrm{X}$ terhadap $\mathrm{Y}$ dapat ditentukan dengan menggunakan rumus koefisien determinan. Koefisien 
determinan adalah kuadrat dari koefisien korelasi PPM dikalikan 100\%. Koefisien determinan diuji untuk mengetahui seberapa besar variabel $\mathrm{X}$ mempunyai kontribusi atau ikut menentukan variabel Y.

Untuk mengetahui hubungan antara $X_{1}$ dan $X_{2}$ secara bersama-sama terhadap variabel $\mathrm{Y}$ digunakan rumus korelasi ganda.

\section{Uji Analisis Regresi Sederhana dan Ganda}

Untuk mencari hubungan antar variabel digunakan Uji Regresi. Kemudian dilanjutkan dengan Uji-F. Uji-F dilakukan untuk melihat kebermaknaan model regresi dan bentuk hubungan variabel yang dihubungkan. Dalam uji ini digunakan regresi linier dan regresi ganda.

\section{Uji Analisis Jalur (Path Analysis)}

Teknik analisis jalur (Path Analysis) digunakan untuk menguji besarnya kontribusi yang ditunjukkan oleh koefisien jalur pada setiap diagram jalur dari hubungan kausal antar variabel $X_{1}, X_{2}, X_{3}$ terhadap $Y_{1}$ dan $Y_{2}$. Pengujian secara keseluruhan variabel dihitung dengan rumus $\mathrm{F}$, dengan $\mathrm{Sig}<0,05$. Dan pengujian secara individual variabel penelitian akan diuji dengan uji t, dengan Sig $<0,05$.

Selanjutnya untuk mengetahui signifikansi analisis jalur adalah membandingkan nilai probabilitas 0,05 dengan nilai probabilitas Sig dengan dasar pengambilan keputusan sebagai berikut:

1. Jika nilai probabilitas 0,05 lebih kecil atau sama dengan nilai probabilitas Sig atau $[0,05 \leq \mathrm{Sig}]$, maka Ho diterima dan Ha ditolak, artinya tidak signifikan.

2. Jika nilai probabilitas 0,05 lebih besar atau sama dengan nilai probabilitas Sig atau $[0,05 \geq$ Sig], maka Ho ditolak dan Ha diterima, artinya signifikan.

\section{HASIL DAN PEMBAHASAN \\ Hasil \\ Hubungan Motivasi Berprestasi terhadap Hasil Belajar Kognitif Biologi}

Berdasarkan hasil uji regresi motivasi berprestasi terhadap hasil belajar kognitif biologi diketahui nilai $r=0,536$ yang tergolong dalam kategori cukup kuat, dimana tingkat keeratan hubungan variabel $\mathrm{X}_{1}$ terhadap $\mathrm{Y}_{1}$ sangat signifikan dengan nilai $(\mathrm{F}=110,020 ; \mathrm{P}=0,000)$ maka hipotesis nihil $\left(\mathrm{H}_{01}\right)$ yang menyatakan tidak terdapat hubungan yang signifikan antara motivasi berprestasi terhadap hasil belajar kognitif biologi ditolak, sehingga hipotesis alternatif $\left(\mathrm{H}_{\mathrm{a} 1}\right)$ yang diterima, artinya bahwa terdapat hubungan yang signifikan antara motivasi berprestasi terhadap hasil belajar kognitif biologi siswa SMA Negeri Sekecamatan Medan Kota.

Hasil koefisien arah regresi antara variabel motivasi berprestasi terhadap hasil belajar kognitif biologi diperoleh sebesar 0,199 dengan konstanta (a) sebesar 62,409 dan persamaan regresinya adalah $\hat{\mathrm{Y}}=\mathrm{a}+$ bX, maka: $62,409+0,199$. Artinya siswa mendapatkan motivasi berprestasi dan telah memiliki hasil belajar kognitif biologi sebesar 62,409 dan setiap kenaikan motivasi berprestasi maka akan bertambah pula hasil belajar siswa sebesar 0,199. Nilai koefisien korelasi $\left(\mathrm{R}_{\mathrm{x} 1 \mathrm{y} 1}^{2}\right)$ adalah 0,287, sehingga kontribusi motivasi berprestasi terhadap hasil belajar kognitif biologi sebesar $28,7 \%$.

\section{Hubungan Minat Terhadap Hasil Belajar Kognitif Biologi}

Berdasarkan hasil uji regresi minat terhadap hasil belajar kognitif biologi diketahui nilai $r=0,482$ yang tergolong dalam kategori cukup kuat, dimana tingkat keeratan hubungan variabel $\mathrm{X}_{2}$ terhadap $\mathrm{Y}_{1}$ sangat signifikan dengan nilai $(\mathrm{F}=82,754$ ; $\mathrm{P}=0,000)$ maka hipotesis nihil $\left(\mathrm{H}_{01}\right)$ yang menyatakan tidak terdapat hubungan yang signifikan antara minat terhadap hasil belajar kognitif biologi ditolak, sehingga hipotesis alternatif $\left(\mathrm{H}_{\mathrm{a} 1}\right)$ yang diterima, artinya bahwa terdapat hubungan yang signifikan antara minat terhadap hasil belajar kognitif biologi siswa SMA Negeri Sekecamatan Medan Kota.

Hasil koefisien arah regresi antara variabel minat terhadap hasil belajar 
kognitif biologi diperoleh sebesar 0,283 dengan konstanta (a) sebesar 67,941 dan persamaan regresinya adalah $\hat{\mathrm{Y}}=\mathrm{a}+\mathrm{bX}$, maka: 67,941 + 0,283. Artinya siswa mendapatkan minat dan telah memiliki hasil belajar kognitif biologi sebesar 67,941 dan setiap kenaikan minat maka akan bertambah pula hasil belajar siswa sebesar 0,283. Nilai koefisien korelasi $\left(\mathrm{R}^{2} \mathrm{x} 2 \mathrm{y1}\right)$ adalah 0,233 , sehingga kontribusi minat terhadap hasil belajar kognitif biologi sebesar $23,3 \%$.

\section{Hubungan Perhatian Orang Tua terhadap Hasil Belajar Kognitif Biologi Siswa}

Berdasarkan hasil uji regresi perhatian orang tua terhadap hasil belajar kognitif biologi diketahui nilai $r=0,250$ yang tergolong dalam kategori rendah, dimana tingkat keeratan hubungan variabel $\mathrm{X}_{3}$ terhadap $\mathrm{Y}_{1}$ sangat signifikan dengan nilai $(\mathrm{F}=18,141 ; \mathrm{P}=0,000)$ maka hipotesis nihil $\left(\mathrm{H}_{01}\right)$ yang menyatakan tidak terdapat hubungan yang signifikan antara perhatian orang tua terhadap hasil belajar ditolak, sehingga hipotesis alternatif $\left(\mathrm{H}_{\mathrm{a} 1}\right)$ yang diterima, artinya bahwa terdapat hubungan yang signifikan antara perhatian orang tua terhadap hasil belajar kognitif biologi siswa SMA Negeri Sekecamatan Medan Kota.

Hasil koefisien arah regresi antara variabel perhatian orang tua terhadap hasil belajar kognitif biologi diperoleh sebesar 0,109 dengan konstanta (a) sebesar 74,004 dan persamaan regresinya adalah $\hat{\mathrm{Y}}=\mathrm{a}+$ bX, maka: 74,004 + 0,109. Artinya siswa mendapatkan perhatian orang tua dan telah memiliki hasil belajar sebesar 74,004 dan setiap kenaikan perhatian orang tua maka akan bertambah pula hasil belajar siswa sebesar 0,109. Nilai koefisien korelasi $\left(\mathrm{R}_{\mathrm{x} 3 \mathrm{y} 1}^{2}\right)$ adalah 0,062 , sehingga kontribusi perhatian orang tua terhadap hasil belajar kognitif biologi sebesar 6,2\%.

\section{PEMBAHASAN \\ Motivasi Berprestasi terhadap Hasil Belajar Kognitif Biologi}

Berdasarkan data hasil penelitian yang diperoleh masing-masing dari 275 responden siswa SMA Negeri Sekecamatan Medan Kota diketahui bahwa nilai rata-rata tingkat motivasi berprestasi siswa sebesar 110,52 yang termasuk dalam kategori tinggi dan hasil belajar kognitif biologi sebesar 84,43 yang termasuk dalam kategori sangat tinggi. Namun diperoleh nilai $\mathrm{r}=0,536$ yang tergolong dalam kategori cukup kuat, yang memiliki kontribusi motivasi berprestasi terhadap hasil belajar kognitif biologi sebesar $28,7 \%$. Dalam hal ini terdapat hubungan positif antara motivasi berprestasi terhadap hasil belajar kognitif biologi siswa, dimana orang yang memiliki motivasi berprestasi tinggi akan bersifat positif terhadap hasil belajarnya dibandingkan dengan orang yang memiliki motivasi berprestasi rendah.

Hal tersebut sejalan dengan hasil penelitian oleh Rahmi (2013) yang menyimpulkan bahwa motivasi belajar memiliki hubungan dan kontribusi yang positif terhadap hasil belajar siswa. Penelitian oleh Davies (1981) yang mengatakan bahwa motivasi mempunyai pengaruh penting dalam pembelajaran, yaitu: (1) Motivasi memberi semangat kepada siswa, sehingga siswa menjadi aktif, sibuk, dan tertarik karena motivasi menopang upaya-upaya dan menjaga (belajar) siswa tetap jalan; (2) Motivasi mengarahkan dan mengendalikan tujuan, siswa melengkapi suatu tugas, mencapai tujuan khusus yang diinginkan; (3) Motivati adalah selektif, dimana siswa dapat menentukan kegiatan apa yang akan dilakukan dan bagaimana tugas-tugas itu akan dilakukan. Dengan demikian, motivasi berfungsi sebagai penentu prioritas untuk keberhasilan seseorang termasuk keberhasilan dalam belajar. Berarti motivasi berprestasi mendorong atau memberi semangat kepada siswa untuk meningkatkan prestasi belajar.

Mc Clleland (1976) mengatakan bahwa motivasi berprestasi mengandung dua aspek, yaitu: (1) Mencirikan ketahanan dan suatu ketakutan akan kegagalan; dan (2) Meningkatkan usaha keras yang berguna dan mengharapkan akan keberhasilan. Hal ini sejalan dengan Travers (1982) yang berpendapat bahwa 
ada dua kategori penting dalam motivasi berprestasi, yaitu mengharapkan akan sukses dan takut akan kegagalan. Selanjutnya, dikatakan seseorang menjadi sukses atau gagal, bila dimotivasi oleh kebutuhan untuk berprestasi.

\section{Minat terhadap Hasil Belajar Kognitif Biologi}

Berdasarkan data hasil penelitian yang diperoleh masing-masing dari 275 responden siswa SMA Negeri Sekecamatan Medan Kota diketahui bahwa nilai rata-rata tingkat minat siswa sebesar 58,26 yang termasuk dalam kategori tinggi dan hasil belajar kognitif biologi sebesar 84,43 yang termasuk dalam kategori sangat tinggi. Namun diperoleh nilai $\mathrm{r}=0,482$ yang tergolong dalam kategori cukup kuat, yang memiliki kontribusi minat terhadap hasil belajar kognitif biologi sebesar $23,3 \%$. Dalam hal ini terdapat hubungan positif antara minat terhadap hasil belajar kognitif biologi siswa, dimana orang yang memiliki minat tinggi akan bersifat positif terhadap hasil belajarnya dibandingkan dengan orang yang memiliki minat rendah.

Minat belajar merupakan salah satu hal yang perlu ada untuk mencapai hasil belajar siswa agar prestasi belajar diperoleh secara maksimal. Hal ini sejalan dengan penelitian oleh Widiyanto (2007) yang menyatakan bahwa ada pengaruh positif dan signifikan dari minat belajar terhadap prestasi belajar siswa.

\section{Perhatian Orang Tua terhadap Hasil Belajar Kognitif Biologi}

Berdasarkan data hasil penelitian yang diperoleh masing-masing dari 275 responden siswa SMA Negeri Sekecamatan Medan Kota diketahui bahwa nilai rata-rata tingkat perhatian orang tua sebesar 95,21 yang termasuk dalam kategori tinggi dan hasil belajar kognitif biologi sebesar 84,43 yang termasuk dalam kategori sangat tinggi. Namun diperoleh nilai $\mathrm{r}=0,250$ yang tergolong dalam kategori rendah, yang memiliki kontribusi perhatian orang tua terhadap hasil belajar kognitif biologi sebesar 6,2\%. Dalam hal ini terdapat hubungan positif antara perhatian orang tua terhadap hasil belajar kognitif biologi siswa, dimana orang yang memiliki perhatian orang tua tinggi akan bersifat positif terhadap hasil belajarnya dibandingkan dengan orang yang memiliki perhatian orang tua rendah.

Lingkungan belajar merupakan tempat dimana seseorang melakukan aktivitas pembelajaran. Lingkungan belajar akan mempengaruhi keberhasilan seseorang dalam mencapai suatu hasil belajar biologi yang maksimal. Pengaturan lingkungan belajar juga dibutuhkan oleh seseorang untuk mengontrol atas pemenuhan kebutuhan emosional mereka yaitu tepatnya pengaruh dari perhatian orang tua terhadap prestasi belajar anaknya. Menurut Papalia (2008) orang tua terutama ibu dapat mempengaruhi prestasi belajar anak mereka dengan melibatkan diri dalam pendidikan anak dengan bertindak sebagai penasehat bagi anak mereka dan memberi kesan pada guru tentang keseriusan target pendidikan yang harus dicapai didalam keluarga.

Menurut Gunarsa (2008) seorang ibu menjadi tokoh sentral dan memiliki peran penting dalam membangun relasi antar remaja dan orang tuanya. Setiap ibu memiliki peran pemeliharaan, pengasuhan dan pendidikan yang baik sebagai dasar dalam pembentukan kepribadian anak.

\section{KESIMPULAN}

Dari hasil penelitian dan pembahasan, maka dapat disimpulkan bahwa terdapat hubungan yang signifikan antara motivasi berprestasi terhadap hasil belajar kognitif biologi dengan perolehan nilai $(r=0,536$; $\mathrm{p}=0,000$ ) yang tergolong dalam kategori cukup kuat.(2) Terdapat hubungan yang signifikan antara minat terhadap hasil belajar kognitif biologi dengan perolehan nilai $(\mathrm{r}=0,482 ; \mathrm{p}=0,000)$ yang tergolong dalam kategori cukup kuat.(3)Terdapat hubungan yang signifikan antara perhatian orang tua terhadap hasil belajar kognitif biologi dengan perolehan nilai $(r=0,250$; $\mathrm{p}=0,000$ ) yang tergolong dalam kategori rendah. 
DAFTAR PUSTAKA

Davies, Ivor K. 1981. Instructional Technique. New York: McGrow-Hill Book Company. Mc Clelland, D.C. 1987. Human Motivation. Cambridge: Cambridge Univ-Press.

Siregar dan nara. 2010. Teori Belajar dan Pembelajaran. Bogor: Ghalia Indonesia.

Soemanto, W. 1990. Psikologi Pendidikan. Jakarta: Rineka Cipta.

Travers, Robert M. W. 1982. Essential of Learning; The New Cognitive Learniong for Students of Education. United State of American: Macmillan Publishing Co. Inc.

Widiyanto. 2007. Pengaruh Iklim Belajar, Motivasi Belajar Siswa dan Semangat Kerja Guru terhadap Prestasi Belajar Siswa Kelas 3 SMK Pembaharuan Tahun Pelajaran 2006/2007. Purwekerto: Universitas Jenderal Sudirman.

Yamin, M. 2008. Desian Pembelajaran Berbasis Tingkat Satuan Pendidikan. Jakarta : Gaung Persada Press 